Special Issue: Agricultural Productivity and Sustainability Improvement in Tropical Region

\title{
Analysis of Metabolites from Purple Cleome Extract (Cleome rutidosperma Linn.) as Potential Organic Fungicides
}

\author{
Ali Ikhwan ${ }^{1 *}$, Dian Indratmi ${ }^{1}$, Faridlotul Hasanah ${ }^{1}$, Manar Fayiz Mousa Atoum $^{2,3}$ and Irum Iqrar ${ }^{4,5}$
}

${ }^{1}$ Department Agrotechnology, Faculty of Agriculture and Animal Science, University of Mubammadiyah Malang, Jl. Raya Tlogomas No. 246, Malang 65144, Indonesia; ${ }^{2}$ Molecular Biology and Genetics, The Hashemite University, PO Box 330127, 13133 Zarqa, Jordan; ${ }^{3}$ Department of Medical Laboratory Sciences, The Hashemite University; ${ }^{4}$ Department of Biotechnology, Quaid-i-Azam University, NCB Building Islamabad 45320, Pakistan; ${ }^{5}$ Pakistan Academy of Sciences, 3 Constitution Ave, G-5/2, Islamabad Capital Territory, Pakistan.

Abstract | One disease that often attacks chili (Capsicum L.) is anthracnose caused by Colletotrichum capsici [(Syd.) E.J. Butler \& Bisby]. In the field, C. capsici is controlled with a chemical fungicide that harms the environment. The purple Cleome plant (Spider plant - Cleome rutidosperma Linn.) can be extracted and function as an organic fungicide for environment-friendly control. This research aimed to examine the type and concentration of purple cleome extract metabolites and understand their effectiveness in inhibiting C. capsici. Purple cleome leaf is extracted with $1: 1 \mathrm{w} / \mathrm{v}$ absolute methanol and concentrated with $1: 1 \mathrm{v} / \mathrm{v}$ cold absolute methanol, and then the supernatant is purified using a centrifuge. The metabolic analysis was performed using Gas Chromatography-Mass Spectrometry (GC-MS) and comparing the data with the National Center for Biotechnology Information (NCBI) database to obtain specific metabolites. The inhibition test was done with one control (P0: chemical fungicide) and two-level of treatment, i.e., the concentration of purple Cleome extract (P1: $80 \%$ and P2: $40 \%$ ), then ANOVA and HSD test were carried out to find out the best treatment. The purple Cleome leaf extract contained three metabolite compounds as organic fungicides, namely propanoic acid $4.12 \%$, phenol $8.38 \%$, and isopropyl myristate $15.86 \%$. The inhibition test confirmed that $80 \%(\mathrm{P} 2)$ purple cleome extract could suppress $C$. capsici attack up to $16.67 \%$, significantly higher than chemical fungicide $(24.4 \%)$.

Received | September 26, 2021; Accepted | December 21, 2021; Published | December 28, 2021

*Correspondence | Ali Ikhwan, Agrotechnology Department, Faculty of Agriculture and Animal Science, University of Muhammadiyah Malang, Indonesia; Email: aliikhwan64@gmail.com

Citation | Ikhwan, A., D. Indratmi, F. Hasanah, M.F.M. Atoum and I. Iqrar. 2021. Analysis of Metabolites from Purple Cleome Extract (Cleome rutidosperma Linn.) as Potential Organic Fungicides. Sarhad Journal of Agriculture, 37(Special issue 1): 115-121.

DOI | https://dx.doi.org/10.17582/journal.sja/2021/37.s1.115.121

Keywords | Chili, Disease control, Environment-friendly control, Reduce chemical fungicide, Spider plant

\section{Introduction}

$\mathrm{B}$ ased on observations in the field, farmers often still experience difficulties growing chili (Capsicum L.) plants due to many pests and diseases that attack. One disease that usually attacks is anthracnose disease on chili by Colletotrichum capsici [(Syd.) E.J. Butler \& Bisby] fungus results in crop losses reaching $65 \%$ (Salim, 2012). According to Herwidyarti et al. (2013), it is stated that anthracnose disease is a salient disease that can reduce chili production by $20 \%$ to $90 \%$. Anthracnose is a disease that is difficult to control because of the sudden and fatal spread, so it needs proper and environmentally friendly control.

One way to overcome these pathogens is to spray plant extract, e.g., purple cleome plant (spider or bee plant - Cleome rutidosperma Linn.) extracts as organic fungicides (Aliyu and Prasad, 2020). Purple Cleome plant extract has a chemical compound, thiogluco- 
side or glucosinolate, which can release isothiocyanate, which acts as a poison for the pest. In addition, purple Cleome plants have alkaloid and flavonoid metabolites that are potentially organic pesticides and fungicides (Panche et al., 2016; Stankovic et al., 2020; Yun and Dong, 2016). Therefore, GC-MS (Gas Chromatography-Mass Spectrometry) analyses were performed to determine the secondary metabolite compounds in purple Cleome leaves.

GC-MS is a method of separating organic compounds consisting of two methods of compound analysis, namely gas chromatography (GC) which is used to analyze compounds quantitatively, and mass spectrometry (MS) which is used to analyze the molecular structure of qualitative analytical compounds (Kalurachchi et al., 2017). Gas chromatography is a spectroscopic technique using the principle of separation of mixtures based on differences in the migration rates of each constituent component. Gas chromatography is used to identify a compound contained in the gas mixture and determine the compound's concentration in the gas phase. Mass spectrometry is a method for obtaining molecular weight by finding the ratio of mass to the charge of ions in which the charge is known by measuring the radius of its circular orbit in a magnetic field (Büyükköroğlu et al., 2018; Fiehn, 2017).

Cleome sp., e.g., Cleome viscosa L., Cleome coluteoides Boiss., and Cleome isocandra L., the extract has been found to have antioxidant and other compounds with antimicrobial properties, including antimicrobial properties antifungal activity. $C$. viscosa is wellknown for its antioxidant compounds, including gallotannins, gallic acid, saponins, iridoid, and terpenoid, while C. spinosa contains flavonoids, phenolics, and cleomeprenols (Upadhyay, 2015). Furthermore, the study reported by Deventhiran et al. (2017) and Jana and Biswas (2011) showed that C. viscosa is used to treat infection, and lactam nonanoic acid is isolated from its root exudates has inhibitory activity on fungi due to its allelopathic and antimicrobial properties. Besides, Moghaddam et al. (2021) reported that C.coluteoides has antifungal activity against Fusarium sola$n i$ and Candida albicans while Gowdra et al. (2019) stated that $C$. isocandra is able to inhibit the mycelial growth and spore germination of Alternaria solani Sorauer.

Regarding the use of organic approach to control Col- lectotrhicum sp., various plant extracts, e.g., Curcuma longa L., Jasminum L., Ficus septica Burm.f., Lantana birta Graham, Argemone ochroleuca Sweet., and Adenophyllum porophyllum (Cav.) Hemsl. has been researched to investigate the use of organic antifungal agents Collectothricum sp., including Collectothricum cocodes, Colletotrichum acutatum J.H. Simmonds, and Colletothricum gleosporioides (Penz.) Penz. \& Sacc. although the studies mostly undergo in vitro tests (Hernández-Ceja et al., 2021; Sudirga et al., 2014; Zaker, 2016). A review was written by Gowdra et al., (2019) also presented fungi toxic effects of various plant extracts even cow urine against $C$. capsici. Johnny et al. (2011) and Shinde and Gawai (2014) also contributed to an investigation on antifungal properties of various plant extracts towards C. capsici. Johnny et al. (2011) found that Piper betle L. has the most effective and the highest antifungal activities, i.e., inhibited $85.25 \%$ of radial growth of C. capsici, amongst the fifteen tested plant extracts, while Shinde and Gawai (2014) reported that Azadiracha indica A.Juss. and Ocimum sanctum Linn. have strong inhibitory activity (63\% to $68 \%$ ) for the growth of $C$. capsici among seven tested plant extracts. So, there is very limited information about the use of $C$. rutidosperma as an antifungal or organic fungicide against C. capsici.

This research is intended to examine more in-depth the type and concentration of purple Cleome extract metabolites that act as organic fungicides in the pathogenic fungus $C$. capsici and understand their effectiveness in inhibiting the pathogens that attack chili plants.

\section{Materials and Methods}

\section{Analysis of metabolites of purple cleome extract}

Extraction: The purple cleome plant was acquired as a weed with $30 \mathrm{~cm}$ to $50 \mathrm{~cm}$ height and stored as a fresh leaf for the extraction procedure. The selected purple cleome leaf sample was the fifth leaf from the shoot or mature enough to extract the secondary metabolites. Purple Cleome leaf was extracted using absolute methanol 1:1 w/v and shook overnight for $16 \mathrm{~h}$ at $150 \mathrm{rpm}, 1 \mathrm{rpm}=1 / 60 \mathrm{~Hz}$ (Intelligent Orbital Shaker Model MS-1, China). The extractant obtained was concentrated with cold absolute methanol $\left(4{ }^{\circ} \mathrm{C} \pm 1{ }^{\circ} \mathrm{C}\right)$ at a ratio of $1: 1 \mathrm{v} / \mathrm{v}$, and the supernatant was purified by a $4000 \mathrm{rpm}$ centrifugation (Hettich EBA 12, USA) system for $5 \mathrm{~min}$. 
Metabolite Analysis: Metabolic analysis of purple Cleome leaf extract was done using GC-MS (Gas Chromatography-Mass Spectrometry) type QP2010S Shimadzu (Japan), semi-polar column $\mathrm{RXi}-5 \mathrm{MS}$, with helium carrier gas flow rate of 0.5 $\mathrm{mL} \min ^{-1}$, and pressure $27.4 \mathrm{kPa}$. The initial temperature of the GC $120{ }^{\circ} \mathrm{C}$ oven was increased with a speed of $5{ }^{\circ} \mathrm{C} \mathrm{min}{ }^{-1}$ until it reached $320{ }^{\circ} \mathrm{C} \mathrm{min}-1$ and the sample volume of $1 \mathrm{uL}$ to $2 \mathrm{uL}$ (Ahmed and Annadurai, 2017). The data obtained were analyzed with the NCBI (National Center for Biotechnology Information) database to obtain specific metabolites that act as organic fungicides.

\section{Test for purple cleome as organic fungicide}

Pathogen Inoculation in Chili: Pathogen inoculation of $100 \mathrm{~g}$ chili was done by spraying $5 \mathrm{~mL}$ inoculum on the surface of fresh Chili. The chili fruit extracted was put into a hollow plastic mica and stored at room temperature of $28{ }^{\circ} \mathrm{C}$.

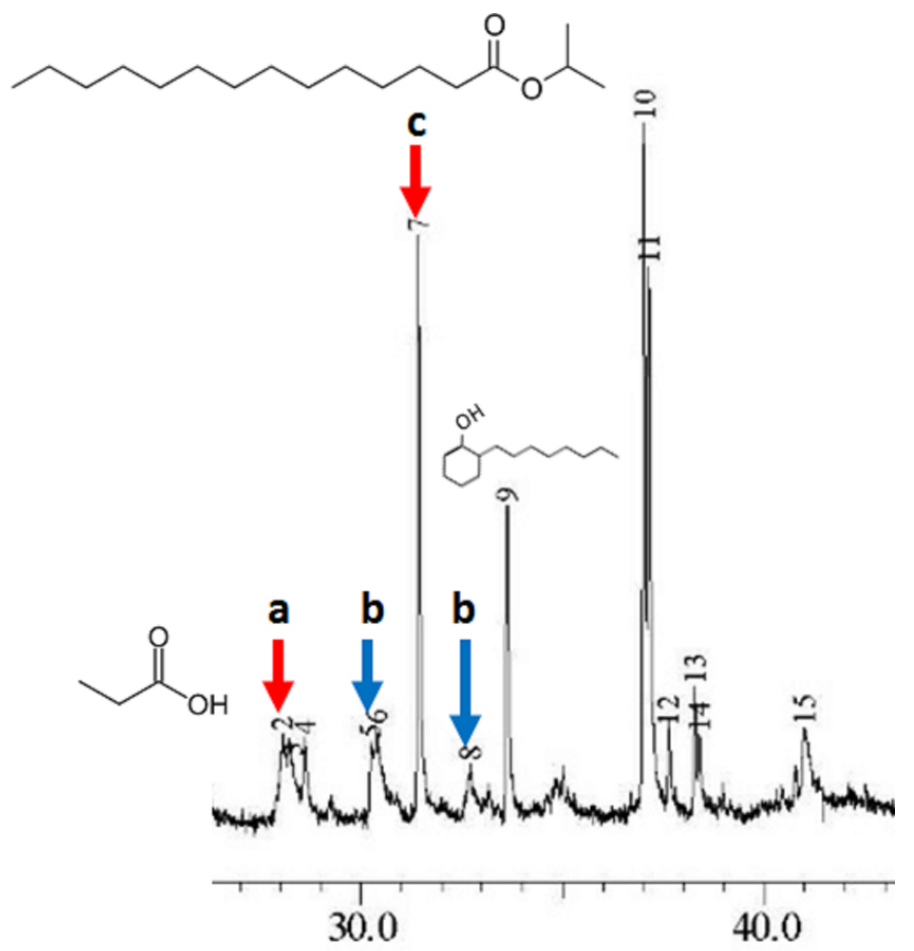

Figure 1: Chromatogram results of $G C-M S$ analysis of purple Cleome leaf extract, (a) Propanoic acid, (b) Phenol, and (c) Isopropyl myristate.

Inhibition test of Purple Cleome extract on C.capsica: The inhibition test was carried out using a simple randomized complete trial design with $80 \%(\mathrm{P} 1)$ and $40 \%(\mathrm{P} 2)$ purple Cleome extract concentration with chemical fungicide (Antracol $70 \mathrm{WP}$, with the active ingredient Propineb $70 \%$, produced by Bayer Indonesia) (P0) control. Every 3 d, purple Cleome extract is sprayed evenly on chilies that have been inoculated with pathogens and repeated three times. Observations were made every $3 \mathrm{~d}$ with observational parameters: (i) diseases incidence, with Equation (1), (ii) the disease severity index, with Equation (2), and (iii) the weight loss of the fruit, with Equation (3) and measured according to Supriatna et al. (2017).

Diseases incidence $(\%)=\frac{\text { sum of fruits sample attacked }}{\text { sum of total fruit sample }} \times 100 \ldots$.
Disease severity index $(\%)=\frac{\left.\sum \text { (class frequency } \times \text { score of rating class }\right)}{\text { total number of fruits } \times \text { maximal disease index }} \ldots$

Weight shrinkage $(\%)=\frac{\text { initial weight of fruits }- \text { fruits weight at observed time }}{\text { initial weight of fruits }} \times 100 \ldots$ (3)

The data were analyzed by ANOVA. To determine the difference in treatment, a comparative test of Tukey's honestly significance difference (HSD) $5 \%$ was carried out if the treatment proved to be influential (Adinurani, 2016).

\section{Results and Discussion}

\section{Analysis of purple cleome leaf extract}

GC-MS analysis: GC-MS results obtained 18 metabolites, and three of them were characterized as organic fungicides, namely: propanoic acid, phenol, and isopropyl myristate, as shown in the chromatogram (Figure 1) as follows:

\section{Analysis of metabolite as a fungicide}

GC-MS analysis results obtained three metabolite compounds that act as organic pesticides, namely propanoic acid, phenol, and isopropyl myristate, with a total composition of $28.36 \%$, which acts as an antifungal and anti-bacterial as shown in Table 1.

The mechanism of inhibiting microorganisms by Propanoic acid varies depending on the type of $\mathrm{mi}^{-}$ croorganism. The mechanism in inhibiting microbes is competition with acetate in the acetokinase system, namely the blockage of pyruvate to acetyl coenzyme-A and B-alanine to inhibit microbes. Antifungal activity by propanoic acid compounds is due to the performance of propionyl-CoA, which inhibits glucose metabolism in certain fungal species through the accumulation of CoA derivatives (May and Sang-Keun, 2016).

Phenol acts as a toxic and corrosive antimicrobial that irritates the fungal cell wall. The mechanism 
of the performance of phenol compounds is by destroying the hydrophobic bonding components of the cell membrane, such as proteins and phospholipids. Damage to the cell membrane can inhibit the activity and biosynthesis of specific enzymes that play a role in metabolism. Moreover, phenol acts as an inhibitor of essential enzymes in cells and can be used as an active antimicrobial agent against vegetative cells of bacteria, viruses, fungi, and conversely inactive against bacterial spores. Phenol can reduce the permeability of cytoplasmid membrane on fungi so that the membrane is damaged and results in stunted cell growth or even cell death (Ghosh et al., 2019).

Table 1: Results of the metabolism analysis of purple Cleome extract which acts as an organic fungicide.

\begin{tabular}{|c|c|c|c|}
\hline No. & $\begin{array}{l}\text { Compound } \\
\text { Name (CAS) }\end{array}$ & $\begin{array}{l}\text { Composi- } \\
\text { tion (\%) }\end{array}$ & Function \\
\hline 1. & $\begin{array}{l}\text { Propanoic acid } \\
\mathrm{C}_{11} \mathrm{H}_{14} \mathrm{O}_{2}\end{array}$ & $4.12 \%$ & $\begin{array}{l}\text { Acts as an anti-fungal and } \\
\text { anti-bacterial by inhibiting } \\
\text { their growth (Yun and Dong, } \\
\text { 2016). }\end{array}$ \\
\hline \multirow[t]{2}{*}{2.} & $\begin{array}{l}\text { Phenol } \\
\mathrm{C}_{17} \mathrm{H}_{28} \mathrm{O}\end{array}$ & $8.38 \%$ & $\begin{array}{l}\text { Acts as an anti-microbial that } \\
\text { is toxic and corrosive. Phenol } \\
\text { can damage the hydrophobic } \\
\text { bonds that makeup cell mem- } \\
\text { branes such as proteins and } \\
\text { phospholipids. }\end{array}$ \\
\hline & & & $\begin{array}{l}\text { Acts as an inhibitor of es- } \\
\text { sential enzymes and as active } \\
\text { anti-microbial vegetative } \\
\text { cells of bacteria, viruses, and } \\
\text { fungi. Phenol can reduce the } \\
\text { permeability of cytoplasmic } \\
\text { membrane and dead fungal } \\
\text { cells (Ariyanti } \text { et al., 2012) }\end{array}$ \\
\hline 3. & $\begin{array}{l}\text { Isopropyl } \\
\text { myristate } \\
\mathrm{C}_{17} \mathrm{H}_{34} 0_{2}\end{array}$ & $15.86 \%$ & $\begin{array}{l}\text { Act as an active ingredient of } \\
\text { pesticides } \\
\text { (Bessette, and Brentwood, } \\
\text { 2007). }\end{array}$ \\
\hline
\end{tabular}

Table 2: Disease incidence of C. capsici fungus on chili.

\begin{tabular}{|c|c|c|c|}
\hline Treatment & $\begin{array}{l}1^{\text {st }} \text { obser- } \\
\text { vation }\end{array}$ & $\begin{array}{l}2^{\text {nd }} \text { obser- } \\
\text { vation }\end{array}$ & $\begin{array}{l}3^{\text {rd }} \text { obser- } \\
\text { vation }\end{array}$ \\
\hline P0 (chemical pesticide) & $20.83 a$ & $23.81 \mathrm{a}$ & $24.4 \mathrm{a}$ \\
\hline $\begin{array}{l}\text { P1 (80 \% purple Cleome } \\
\text { extract) }\end{array}$ & $13.89 a$ & $15.56 b$ & $16.67 \mathrm{~b}$ \\
\hline $\begin{array}{l}\text { P2 (40\% purple Cleome } \\
\text { extract) }\end{array}$ & $16.86 \mathrm{a}$ & $18.02 \mathrm{ab}$ & $19.77 \mathrm{ab}$ \\
\hline
\end{tabular}

Note: numbers followed by the same letter indicate no significant difference according to the LSD test level of $5 \%$

Isopropyl myristate acts as a catalyst for active ingredients of pesticides. For example, Besette (2006) states that isopropyl myristate in pesticides containing pyrethrum can kill insects.

Thus the results of GC-MS analysis of purple Cleome extracts identified specific metabolites in the form of propanoic acid (4.12\%), phenol (8.38\%), and isopropyl myristate $(15.86 \%)$, which act as organic fungicides.

\section{In Vitro Fungicide Metabolite Test}

The percentage of $C$. capsici fungi, it appears that the $80 \%$ extract of purple Cleome (P1) containing propanoic acid, phenol, and isopropyl myristate metabolites with concentrations reaching $28.63 \%$ can inhibit fungal attacks more effectively than chemical fungicide (P0) (Table 2). This shows that organic pesticides of $80 \%$ purple Cleome extract can exceed the ability of chemical pesticides to inhibit the fungus Colletotrichum capsici. According to Patil et al. (2012), purple Cleome has a broad spectrum antimicrobial content against several types of fungi and bacterial pathogens and can inhibit the growth of pathogens more effectively.

The severity of the C. capsici fungus attack showed no significant difference between the use of chemical fungicide with purple Cleome leaf extracts (Table 3). This indicates that the effectiveness of using purple Cleome leaf extract as an organic fungicide is equivalent to chemical fungicides in suppressing the attack of the fungus $C$. capsici. Furthermore, according to Silva et al. (2016), purple Cleome metabolites have phytochemicals (flavonoids, terpenoids, and saponins), which act as active ingredients to inhibit pathogenic microbial attacks equivalent to artificial chemicals.

Table 3: Severity index of disease in Chili.

\begin{tabular}{llll} 
Treatment & \multicolumn{3}{l}{ Severity level (\%) } \\
& $\begin{array}{l}\text { 1 }^{\text {st }} \text { obser- } \\
\text { vation }\end{array}$ & $\begin{array}{l}2^{\text {nd }} \text { obser- } \\
\text { vation }\end{array}$ & $\begin{array}{l}3^{\text {rd }} \text { obser- } \\
\text { vation }\end{array}$ \\
P0 (chemical pesticide) & 20.83 a & $34.82 \mathrm{a}$ & $29.27 \mathrm{a}$ \\
P1 (80 \% purple Cleome & $13.89 \mathrm{a}$ & $24.89 \mathrm{a}$ & $29.44 \mathrm{a}$ \\
extract) & & & \\
$\begin{array}{l}\text { P2 (40\% purple Cleome } \\
\text { extract) }\end{array}$ & $16.86 \mathrm{a}$ & $30.23 \mathrm{a}$ & $32.56 \mathrm{a}$
\end{tabular}

Note: numbers followed by the same letter indicate no significant difference according to the LSD test level of $5 \%$

There was no significant difference between chemical fungicides with purple Cleome leaf extract (Table 
4). This shows that the effectiveness of using purple Cleome leaf extract as an organic fungicide is equivalent to chemical fungicides in maintaining the quality of Chili due to the attack of the fungus C. capsici.

Table 4: Percentage of shrinkage weights in Chili.

$\begin{array}{ll}\text { Treatment } & \text { Weight } \\ \text { P0 (chemical pesticide) } & 21.25 \mathrm{a} \\ \text { P1 (80 \% purple Cleome extract) } & 22.00 \mathrm{a} \\ \text { P2 (40 \% purple Cleome extract) } & 27.75 \mathrm{a}\end{array}$

Note: numbers followed by the same letter indicate no significant difference according to the LSD test level of $5 \%$

\section{Conclusions and Recommendations}

The results of GC-MS analysis identified three metabolite compounds in purple Cleome that act as organic fungicides, namely propanoic acid $4.12 \%$, phenol $8.38 \%$, and isopropyl myristate $15.86 \%$. These metabolites can reduce Colletotrichum capsici attack rates to $16.67 \%$ and are more effective than chemical fungicides.

\section{Novelty Statement}

Previous studies on the use of plant extracts as organic fungicides against Colletotrichum capsici have been widely conducted, but the use of $C$. rutidosperma has not been published yet. Furthermore, the application of the antifungal is still limited on the inhibitory activity against $C$. capsici on the agar medium. Still, its application on the fruit has not been much conducted. However, based on the results of this study, $C$. rutidosperma is highly potential as antifungal with the presence of specific metabolites, i.e., propanoic acid, phenol, and isopropyl myristate, which act as organic fungicides and its ability to suppress the C. capsici attack.

\section{Author's Contribution}

AI: Conceptualized and designed research, elaborated intellectual content, statistical data analysis, prepared manuscript and revised.

DI: Carried out experimental studies and reviewed manuscript.

FH: Reviewed manuscript and revised manuscript.

MFMA and II: Elaborated the intellectual content, explored literature search, data acquisition, reviewed manuscript and guarantor.
All authors read and approved the final manuscript.

Conflict of interest

The authors have declared no conflict of interest.

\section{References}

Adinurani, P.G. 2016. Design and analysis of agro trial data: Manual and SPSS. Plantaxia, Yogyakarta, Indonesia.

Ahmed J.S. and A. Annadurai. 2015. GC-MS screening of active secondary metabolites present in the Cleome gynandra.Int.J. Phytopharm. Res.,5(4):47-52. https://doi.org/10.7439/ijpp. v5i4.2474

Aliyu A.W. and M.N.V. Prasad. 2020. African perspective of chemical usage in agriculture and horticulture-their impact on human health and environment. Chapter 16. p 401-436. In: Prasad, M.N.V. (Ed.) Agrochemicals Detection, Treatment and Remediation, Pesticides and Chemical Fertilizers. Elsevier: https://doi. org/10.1016/B978-0-08-103017-2.00016-7

Bessette. S. 2006. Pesticidal compositions containing isopropyl myristate and analogs of same as a synergist for plant essential oils. United States Patent Application Publication: Pub. No.: US 2007/0098750 A1 (https://patents.google. com/patent/US20070098750A1/en)

Büyükköroğlu, G., D.D Dora, F. Özdemir and C. Hizel. 2018. Techniques for protein analysis. Chapter 15. p 317-351 Debmalya, B. and V. Azevedo (Eds.) Omics Technologies and Bio-Engineering. Towards Improving Quality of Life. Academic Press - Elsevier. https://doi. org/10.1016/B978-0-12-804659-3.00015-4

Deventhiran, M., Wyson, W.J., Saravanan, P. and Anand, D. 2017. Evaluation of antioxidant activity of ethanol and chloroform extracts of wild and micropropagated Cleome viscosa linn. Int. J. Pharm., 4(8): 269-272.

Fiehn, O. 2017. Metabolomics by gas chromatography-mass spectrometry: the combination of targeted and untargeted profiling. Curr. Protoc. Mol. Biol., 114 (30.4): 1-32. https://doi. org/10.1002/0471142727.mb3004s114

Ghosh P., M. Biswas, S. Biswas, A. Dutta, L. Hazra, S. Kumar Nag, S. Sil, S. Chatterje. 2019. Phytochemical screening, anti-oxidantand anti-microbial activity of leaves of Cleome Rutidosperma DC. (Cleomaceae). Int. J. Pharm. Sci. 
Res., 11(5): 1790-1795.

Gowdra, N., G. Vijayalakshmi, M.T. Sanjay, C.R. Jahir Basha, N. Mallikarjuna and M. Sharif. 2019. A review on eco-friendly natural plant and animal products for plant diseases management. Int. J. Curr. Microbiol. App. Sci., 8(08): 1957-1977. https://doi.org/10.20546/ ijcmas.2019.808.230

Hernández-Ceja, A., P.D.Loeza-Lara, F.J. Espinosa-García, Y.M. García-Rodríguez, J.R. Medina-Medrano, G.F. Gutiérrez-Hernández and L.F. Ceja-Torres. 2021. In vitro antifungal activity of plant extracts on pathogenic fungi of blueberry (Vaccinium sp.). Plants, 10(852): 1-12. https://doi.org/10.3390/plants10050852

Herwidyarti, K.H., R. Suskandini and J.D. Resiworo. 2013. Severity of anthracnose disease in chili (Capsicum annum L) and various types of weeds. Jurnal Agrotek Tropika,1(1):102-106. https://doi.org/10.23960/jat.v1i1.1925

Jana, A. and S.M. Biswas. 2011. Lactam nonanic acid, a new substance from Cleome viscosa with allelopathic and antimicrobial properties. J. Biosci., 36(1): 27-35. https://doi.org/10.1007/ s12038-011-9001-9

John, S.A. and A. Annadurai. 2015. GC-MS screening of active secondary metabolites present in the Cleome gynandra. Int. J. Phytopharm. Res., 5(4):47-52.

Johnny, L., U.K. Yusuf and R. Nulit. 2011. Antifungal activity of selected plant leaves crude extracts against a pepper anthracnose fungus, Colletotrichum capsici (Sydow) butler and bisby (Ascomycota: Phyllachorales). Afr. J. Biotechnol., 10(20):4157-4165.

Kaluarachchi, M., M.R. Lewis and J.C. Lindon. 2017. Standardized protocols for MS-based metabolic phenotyping. p.224-231. In: Ed. John C. L., G.E. Tranter, and D.W. Koppenaal (Eds.) Encyclopedia of Spectroscopy and Spectrometry. Academic Press, Elsevier Ltd. https:// doi.org/10.1016/B978-0-12-409547-2.121341

May, M.O. and O. Sang-Keun, 2016. Review Article: Chilli anthracnose (Colletotrichum spp.) disease and its management approach. Korean J. Agric. Sci., 43(2): 153-162. https://doi. org/10.7744/kjoas.20160018

Moghaddam,P.Z.,A. Mohammadi,P.Alesheikh,P, Feyzi, A. Haghbin, S. Mollazadeh, Z. Sabeti, A. Nakhlband and J. Kasaian. 2021. Antibacterial, antifungal, and antioxidant activity of Cleome coluteoides: an in vitro comparative study between leaves, stems, and flowers. Turk J. Pharm. Sci., 8(1):10-16. https://doi.org/10.4274/tjps. galenos.2019.59320

Panche N., A.D. Diwan and S.R. Chandra. 2016. Flavonoids: An overview. J. Nutr. Sci., 5: e47. https://doi.org/10.1017/jns.2016.41

Patil R.C., D.W. Swati, S.Y. Sunil and D.D. Vaibhav. 2012. Antibacterial and bioenhancing activity of ethyl acetate extract of Cleome rutidosperma leaves. J. Pharm. Res., 5(1): 557-559.

Salim, A.W. and M.S. Sinaga. 2012. Effectiveness of antagonist agents in controlling Red Pepper damping off. UT - Plant Protection [1382]. Fakultas Pertanian Institut Pertanian Bogor.

Shinde, J.U. and D.U. Gawai. 2014. Efficacy of leaf extracts of some medicinal plants on growth of Colletotrichum capsici butler and bisby. Afr. J. Plant Sci., 8(7): 353-355. https://doi. org/10.5897/AJPS11.217

Silva, A.P.D., L.C.N.D. Silva, C.S.M.D. Fonseca, J.M.D Araujo, M.T.D.S Correia, M.D.S Cavalcanti and V.L.D.M Lima. 2016. Antimicrobial activity and phytochemical analysis of organic extracts from Cleome spinosa Jagc. Front. Microbiol., 7:1-10. https://doi.org/10.3389/ fmicb.2016.00963

Sudirga, S.K., D.N. Suprapta, I.M. Sudana and I.G.N. Wirya. 2014. Antifungal activity of leaf extract of Ficus septica against Colletotrichum acutatum the cause of Anthracnose disease on Chili Pepper. J. Biol. Agric. Healthc. 4(28): 47-52.

Supriatna, A.H, N.F. Haneda and I. Wahyudi . 2017. Population distribution, damage percentage, and damage level due to boktor in sengon: effect of age, diameter and tree height. J. Silv. Trop., 8(2):79-87. https://doi.org/10.29244/jsiltrop.8.2.79-87

Stankovic S., M. Kostic, I. Kostic and S. Krnjajic. 2020. Practical approaches to pest control: The use of natural compounds. p. 1-18. In: Kontogiannatos, D., A. Kourti and K.F.Mendes (eds), Chapter 4, Pests, Weeds and Diseases in Agricultural Crop and Animal Husbandry Production. IntechOpen Limited, London, UK. https://doi.org/10.5772/intechopen.91792

Upadhyay, R.K. 2015. Cleome viscosa Linn: A natural source of pharmaceuticals and pesticides. Int. J. Green Pharm., 9(2):71-85. https://doi. 
org/10.4103/0973-8258.155050

Yun, J. and G.L. Dong. 2016. A novel fungal killing mechanism of propionic acid. FEMS Yeast Res., 16(7) PMID: 27707757: fow089. https:// doi.org/10.1093/femsyr/fow089
Zaker, M. 2016. Natural plant products as ecofriendly fungicides for plant diseases control- A review. Agriculturists, 14(1): 134-141. https:// doi.org/10.3329/agric.v14i1.29111 